\title{
IMPACT OF STOCKING DENSITY ON GROWTH AND PRODUCTION PERFORMANCE OF VIETNAMESE KOI (Anabas testudineus) IN SEMI- INTENSIVE CULTURE SYSTEM AT MUKTAGHASA REGION OF MYMENSINGH DISTRICT
}

Gias Uddin Ahmed, Md. Mamunur Rahman*, Mohammad Nurul Alam, Md. Badrul Alam and Baadruzzoha Sarker ${ }^{1}$

Department of Aquaculture, Faculty of Fisheries, Bangladesh Agricultural University, Mymensingh-2202, Bangladesh; 'Production Officer, BRAC Fish Hatchery Srimangal, Moulvibazar-3210, Bangladesh

*Corresponding author: Md. Mamunur Rahman, E-mail: mamunurrahman125@gmail.com

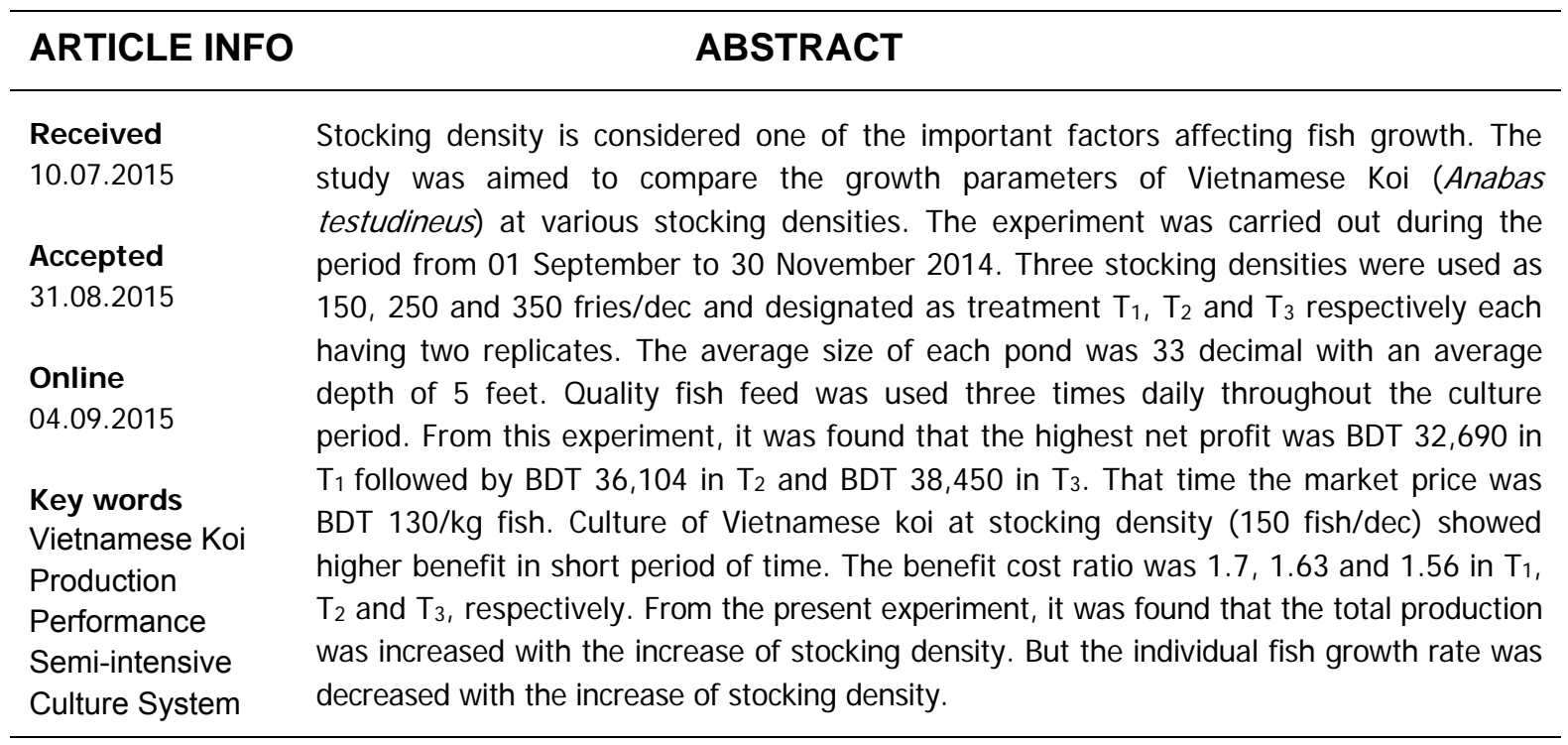

To cite this article: GU Ahmed, MM Rahman' MN Alam, MB Alam and B Sarker, 2015. Impact of stocking density on growth and production performance of Vietnamese koi (Anabas testudineus) in semi-intensive culture system at Muktaghasa region of Mymensingh district. Res. Agric. Livest. Fish. 2 (2): 335-341.

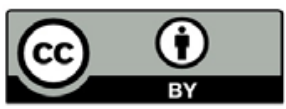

This is an open access article licensed under the terms of the Creative Commons Attribution 4.0 International License

www.agroaid-bd.org/ralf, E-mail: editor.ralf@gmail.com 


\section{INTRODUCTION}

Climbing perch Koi (Anabas testudineus) is an important indigenous fish species of Bangladesh which is very popular for its delicious taste and flavor. According to Saha (1971), the fish contain high values of physiologically available iron and copper essentially needed for hemoglobin synthesis. Once climbing perch was abundantly available in almost all freshwater systems of Bangladesh, however, recently population of this fish has been declining very rapidly. The reasons for such decline are many, such as ecological degradation, indiscriminate fishing, use of pesticides and fertilizers, destruction of habitats, obstruction to breeding migration, management failure, etc. In the face of diminishing natural population of climbing perch-planners, policy makers, aqua culturists, and fisheries biologists are thinking of its cultivation through intensive farming (DOF, 2002). For efficient culture and management of fisheries resources, an understanding of the various factors which have profound influence on the productivity of the water bodies is necessary.

Monoculture and polyculture are practicing culture technique in Bangladesh. The climbing perch fish Anabas testudineus (Bloch) is one of the important freshwater fish of Bangladesh which is locally known as koi in different places of Bangladesh. It contributes $1.4 \%$ in the total inland water fish production (DoF, 20112012). This species considered as a valuable item of diet for sick and convalescent. The breeding technology of native koi (A. testudineus) had successfully been developed in BFRI (Kohinoor, 1991). But the growth rate is very slow in comparison to Thai koi $A$. testudineus. Its slow growth and small size does not favour sustainable production per unit area in aquaculture system (Kohinoor et al., 2009). To overcome this situation, another fast growing climbing perch known as Thai koi ( $A$. testudineus) has been introduced from Thailand in 2002. Although the Thai koi ( $A$. testudineus) is presently used for production purposes by large number of farmers but it is not widely accepted by consumers owing to its body covers with gray colour; small black spots and lack of taste in comparison to native koi ( $A$. testudineus). To improve this situation, another variety of koi known as Vietnamese koi (A. testudineus) have been imported from Vietnam in 2013 by Sarnolata Agro Fisheries Ltd; which is believed to give higher production and faster growth than other variety of koi. A recent report made known that Vietnamese koi grows as big as 250-300g within 4 months culture period with a good FCR and similar body color as native koi. (Sarnolata Agro Fisheries Ltd; 2013). Present study was undertaken to observe the growth performance of Vietnamese koi (A. testudineus) in semi-intensive culture system.

\section{MATERIALS AND METHODS}

This experiment was conducted in "Noha Aqua Farm" at Muktagasha region of Mymensingh for a period of three months from $1^{\text {th }}$ September 2014 to $30^{\text {th }}$ November 2014.

\section{Experimental design}

Table 1. Research layout of Vietnamese koi monoculture

\begin{tabular}{lllll}
\hline Treatment & Replication & $\begin{array}{l}\text { Pond size } \\
\text { (Decimal) }\end{array}$ & $\begin{array}{l}\text { Stocking } \\
\text { density/decimal }\end{array}$ & $\begin{array}{l}\text { Total fries } \\
\text { stocking/pond }\end{array}$ \\
\hline \multirow{2}{*}{$T_{1}$} & $R_{1}$ & 33 & 150 & 4950 \\
& $R_{2}$ & 35 & 150 & 5250 \\
\hline \multirow{2}{*}{$T_{2}$} & $R_{1}$ & 31 & 250 & 7750 \\
\hline \multirow{2}{*}{$T_{3}$} & $R_{2}$ & 34 & 250 & 8500 \\
\hline
\end{tabular}

\section{Collection of fry}

The fry of Vietnamese koi were collected from "Desh Bondhu Matshaya Hatchery”, Mymensingh. 


\section{Selection of feed}

Commercial pellet feed named "Quality Fish Feed" was selected for the present experiment. The Proximate composition of Quality fish feed were Moisture (Max) 12\%, Protein (Min) 35\%, Lipid (Min) 3\% and Fiber (Max) 10\%.

\section{Stocking of fry}

Vietnamese koi fry were $1.0 \mathrm{~g}$ each at the time of directly stocking to the pond.

\section{Feeding Strategy}

At the beginning of the experiment feed was supplied at the rate of $100 \%$ of the body weight of reared Vietnamese koi (1- 8 days) and gradually it was readjusted to 40\% (9-20 days), 20\% (21-30 days), 10\% (3140 days), $5 \%$ (41-60 days) and finally up to harvest at 3\% body weight (61-90 days). No additional feed was supplied. Fish were feed three times daily.

\section{Monitoring and data collection}

Growth monitoring was done at 10 days interval. Fish were caught with the help of cast net. The weight recorded by random sampling of Vietnamese koi with the help of electrical balance.

\section{Analysis of experimental data on growth performances}

(a) Mean weight gain $(\mathrm{g})$ = Final weight- Initial weight

(b) The survival rate was estimated by the following formula:

Survival rate $(\%)=\frac{\text { No. of stocked fishes }}{\text { No.of harvested fishes }} \times 100$

(c) Specific growth rate (SGR \% per day) was estimated by the following formula:

$\operatorname{SGR}(\%$ per day $)=\frac{\log _{\mathrm{e}} W_{2}-\log _{\mathrm{e}} \mathrm{W}_{1}}{\mathrm{~T}_{2}-\mathrm{T}_{1}} \times 100$

Where, $\quad W_{1}=$ Initial live body weight $(\mathrm{g})$ at time $\mathrm{T} 1$ (day).

$\mathrm{W}_{2}=$ Final live body weight $(\mathrm{g})$ at time $\mathrm{T} 2$ (day).

(d) Food conversion ratio $(F C R)=\frac{\text { Feed fed (dry matter) }}{\text { Live weight gain }}$

Data analysis

Data obtained from the present study were analyzed statistically to observe growth performance of different fish species.

\section{RESULTS AND DISCUSSION}

The results of the present experiment regarding compositions of water quality Parameters and growth performance of Vietnamese koi are presented below:

\section{Water quality parameters}

Physical and chemical parameters

The results of the physical and chemical parameters recorded during the experimental period presented in the Table 2 and Table 3. 
Table 2. Fluctuations of physical parameters in culture pond during the experimental period

\begin{tabular}{|c|c|c|c|c|c|c|c|c|c|c|}
\hline Parameter & & & & SaI & oling d & & & & & $\begin{array}{c}\text { Mean } \pm \\
\text { S.D }\end{array}$ \\
\hline \multirow{2}{*}{$\begin{array}{l}\text { Transparency } \\
(\mathrm{cm})\end{array}$} & $\begin{array}{l}10 \\
\text { Sep }\end{array}$ & $\begin{array}{l}20 \\
\text { Sep }\end{array}$ & $\begin{array}{l}30 \\
\text { Sep }\end{array}$ & $\begin{array}{l}10 \\
\text { Oct }\end{array}$ & $\begin{array}{l}20 \\
\text { Oct }\end{array}$ & $\begin{array}{l}30 \\
\text { Oct }\end{array}$ & $\begin{array}{l}10 \\
\text { Nov }\end{array}$ & $\begin{array}{l}20 \\
\text { Nov }\end{array}$ & $\begin{array}{l}30 \\
\text { Nov }\end{array}$ & \\
\hline & 32.33 & 30.00 & 29.00 & 28.00 & 31.00 & 30.33 & 32.33 & 30.33 & 31.20 & $\begin{array}{l}30.50 \pm 2 . \\
04\end{array}$ \\
\hline $\begin{array}{l}\text { Water } \\
\text { temperature } \\
\left({ }^{\circ} \mathrm{C}\right)\end{array}$ & 29.25 & 28.25 & 26.00 & 23.50 & 22.75 & 21.75 & 20.25 & 21.00 & 19.55 & $\begin{array}{l}23.27 \pm 1 \\
37\end{array}$ \\
\hline $\begin{array}{l}\text { Air } \\
\text { temperature } \\
\left({ }^{\circ} \mathrm{C}\right)\end{array}$ & 31.50 & 30.00 & 30.80 & 26.00 & 25.00 & 23.50 & 23.00 & 22.40 & 21.40 & $\begin{array}{l}25.95 \pm 1 \\
04\end{array}$ \\
\hline
\end{tabular}

Wahab et al. (1994) found transparency ranging from $15-55 \mathrm{~cm}$ in polyculture pond. Kohinoor (2000) recorded transparency ranging from 15 to $58 \mathrm{~cm}$. In the present experiment, the transparency values in treatment-1, 2 and 3 were closely near to productive range $(28$ to $32 \mathrm{~cm})$. Aminul (1996) stated that the water temperature ranged from 22 to $34^{\circ} \mathrm{C}$ was suitable for culture of fish. In the present study, range of water temperature was more or less near suitable range for fish culture (19.55 to $29.50^{\circ} \mathrm{C}$ ).

Table 3. Fluctuations of chemical parameters during the experimental period

\begin{tabular}{|c|c|c|c|c|c|c|c|c|c|}
\hline \multirow{2}{*}{ Parameter } & \multicolumn{8}{|c|}{ Sampling Date } & \multirow{2}{*}{$\begin{array}{l}\text { Mean } \pm \\
\text { S.D }\end{array}$} \\
\hline & $\begin{array}{l}10 \\
\text { Sep }\end{array}$ & $\begin{array}{l}20 \\
\text { Sep }\end{array}$ & $\begin{array}{l}30 \\
\text { Sep }\end{array}$ & $\begin{array}{l}10 \\
\text { Oct }\end{array}$ & $\begin{array}{l}20 \\
\text { Oct }\end{array}$ & $\begin{array}{l}30 \\
\text { Oct }\end{array}$ & $\begin{array}{l}10 \\
\text { Nov }\end{array}$ & $\begin{array}{l}20 \\
\text { Nov }\end{array}$ & \\
\hline \multicolumn{10}{|l|}{ Dissolved } \\
\hline $\begin{array}{l}\text { Oxygen } \\
\text { (mg/L) }\end{array}$ & 6.90 & 7.10 & 6.70 & 6.80 & 6.63 & 6.60 & 6.10 & 6.46 & $6.66 \pm 0.34$ \\
\hline $\begin{array}{l}\mathrm{FreeCO}_{2} \\
(\mathrm{mg} / \mathrm{L})\end{array}$ & 3.23 & 2.93 & 3.13 & 3.00 & 2.30 & 2.70 & 2.60 & 2.60 & $2.81 \pm 0.35$ \\
\hline $\mathbf{P}^{H}$ & 7.43 & 7.26 & 6.93 & 7.13 & 6.90 & 7.20 & 7.13 & 7.00 & $7.12 \pm 0.23$ \\
\hline $\begin{array}{l}\text { Total } \\
\text { alkalinity } \\
(\mathrm{mg} / \mathrm{L})\end{array}$ & 50.33 & 48.00 & 53.00 & 49.33 & 52.33 & 50.33 & 51.33 & 50.00 & $50.58 \pm 1.9$ \\
\hline
\end{tabular}

Kohinoor (2000) measured dissolved oxygen 2 to $7.4 \mathrm{mg} / \mathrm{l}$ in the research ponds of Bangladesh Agricultural University campus, Mymensingh. From the above findings, it was concluded that the oxygen content of the present experimental ponds were within the good productive range. During the study period the average fluctuations of free carbondioxide in replication-1, 2 and 3 were range from 2.30 to $3.23 \mathrm{mg} / \mathrm{l}$. The mean values of free carbondioxide were $2.81 \pm 0.35 \mathrm{mg} / \mathrm{l}$ in three replication. Israfil (2000) and Kabir (2003) observed more or less similar results. Fluctuations of the $\mathrm{pH}$ values of the experimental treatments ranged from 6.90 to 7.43 . The mean values of $\mathrm{pH}$ were $7.12 \pm 0.23$ in three replication. Dewan et al. (1991) stated that the optimum $\mathrm{pH}$ range for carp polyculture in pond is 6.5 to 9.0. Israfil (2000) and Kabir (2003) found almost similar results. According to Rahman (1992) total alkalinity of productive ponds should be $20 \mathrm{ppm}$ or more. Total alkalinity in the experimental treatments ranged from 48.00 to $53.00 \mathrm{mg} / \mathrm{l}$. The mean values of total alkalinity were $50.58 \pm 1.98 \mathrm{mg} / \mathrm{l}$ inthree replication. From the above discussion, it may be concluded that all the parameters of experimental ponds were suitable for fish culture. 


\section{Cost-benefit analysis}

From the experiment it was found that the cost of three treatments were BDT 47000, 57236 and 67500 in $\mathrm{T}_{1}, \mathrm{~T}_{2}$ and $\mathrm{T}_{3}$ respectively. Production (kg/Treatment) was $613 \mathrm{~kg}$ in $T_{1}, 718 \mathrm{~kg}$ in $T_{2}$ and $815 \mathrm{~kg}$ in $T_{3}$ and price of fish per $\mathrm{kg}$ was BDT 130 for each treatment.

Table 4. Total production of Vietnamese koi (Anabas testudineus)

\begin{tabular}{ccccccccc}
\hline & $\begin{array}{l}\text { Stocking } \\
\text { fries/dec }\end{array}$ & $\begin{array}{l}\text { Total } \\
\text { Stocking } \\
\text { in both } \\
\text { replica }\end{array}$ & $\begin{array}{l}\text { Initial } \\
\text { weight } \\
\mathbf{( g )}\end{array}$ & $\begin{array}{l}\text { Final } \\
\text { weight } \\
\mathbf{( g )}\end{array}$ & $\begin{array}{l}\text { Total } \\
\text { mortality } \\
\text { (no.) }\end{array}$ & $\begin{array}{l}\text { Survival } \\
\text { rate (\%) }\end{array}$ & $\begin{array}{l}\text { Production } \\
\text { (kg/dec/90 } \\
\text { days) }\end{array}$ & $\begin{array}{l}\text { Production } \\
\text { (kg/acre/90 } \\
\text { days) }\end{array}$ \\
\hline$T_{1}$ & 150 & 5100 & & 121.92 & 65 & 87 & 18 & 1800 \\
$T_{2}$ & 250 & 8125 & 1.0 & 91.08 & 240 & 76 & 22 & 2200 \\
$T_{3}$ & 350 & 11200 & & 75.92 & 465 & 69 & 25 & 2500 \\
\hline
\end{tabular}

Net profit

The net profit in three treatments was BDT 32,690 in $\mathrm{T}_{1}$, BDT 36,104 in $\mathrm{T}_{2}$ and BDT 38,450 in $\mathrm{T}_{3}$

\section{Cost-benefit Ratio}

The Cost-benefit Ratio in three treatments was 1.70 in $T_{1}, 1.63$ in $T_{2}$ and 1.56 in $T_{3}$.

\section{Growth performance of Vietnamese koi}

\section{Mean weight gain (g)}

There was significant difference $(p \leq .01)$ among the different treatments. The highest mean weight gain $(121.92 \pm 1.32 \mathrm{~g})$ was found in treatment $T_{1}$, whereas the lowest mean weight gain $(75.92 \pm 2.65 \mathrm{~g})$ was found in treatment $T_{3}$. The present experiment showed the highest mean weight gain of fish in treatment $T_{1}$ which was stocked at lower densities although same feed and feeding rate were applied in all the treatments. These phenomenon indicated that lower stocking density reduces competition among the fishes which influenced them to take feed properly and it might be absent in the treatments with higher stocking densities. Ahmed et al. (2013) obtained a weight gain of $123.48 \mathrm{~g}$ and $111.82 \mathrm{~g}$ from two different treatments of monosex tilapia for a period of 70 days which were more or less similar to the present study. Ahmed et al. (2015) found the mean lowest weight gain $(94.45 \mathrm{~g})$ which is higher to our present findings.

\section{Specific growth rate (SGR) (\% per day)}

The average values of specific growth rate of Vietnamese koi were observed as $2.590 \%, 2.560 \%$ and $2.598 \%$ in treatments $T_{1}, T_{2}$ and $T_{3}$, respectively. There was no significant difference $(P<0.01)$ among the different treatments. Islam (2007), Begum (2009), Rahim (2010) and Ahmed et al. (2015) who recorded specific growth rate ranged 2.363 to $2.655 \%, 3.65$ to $3.79 \%, 3.09$ to $3.34 \%$ and 2.04 to 2.08 . Islam (2007) obtained the highest values of SGR at the lowest stocking densities which coincide with the present findings.

\section{Survival rate (\%)}

The highest survivability was recorded in $\mathrm{T}_{1}(87 \%)$ and the lowest survivability was in $\mathrm{T}_{3}(69 \%)$. There was significant difference $(P<0.01)$ among the different treatments. Variation in stocking density of fish may change growth and survival rates. According to Kohinoor et al. (2007) survival rate of monosex tilapia were varied from $79 \%$ to $92 \%$. Survival rate was found to be negatively influenced by different stocking densities such as the lowest stocking density showed the highest survivability. It might be due to high competition for food and space among the fishes. 


\section{Production (Kg/dec/90days)}

The highest production was observed to be $25 \mathrm{Kg} / \mathrm{dec} / 90$ days in treatment $\mathrm{T}_{3}$ and the lowest production was observed to be $18 \mathrm{Kg} / \mathrm{dec} / 90$ days in treatment $\mathrm{T}_{1}$. Although the mean weight gain in treatment $\mathrm{T}_{1}$ was highest but total production was highest in treatment $T_{3}$ which might be due to higher stocking densities. Begum (2009) observed the highest production was $14.63 \mathrm{~kg} / \mathrm{dec} / 120$ days which is much higher to our present findings. The present result also supports the findings of Haque (2014) and Hasan (2007) who achieved the higher production from higher stocking densities compared to that achieved with the lower ones.

\section{Benefit-cost analysis}

From this experiment, it was found that the highest net profit was BDT 32,690in $\mathrm{T}_{1}$ followed by BDT 36,104 in $T_{2}$ and BDT 38,450 in T3. That time the market price was BDT 130/kg fish. Culture of Vietnamese koi at stocking density (150 fish/dec) showed higher benefit in short period of time. The benefit cost ratio was 1.7, 1.63 and 1.56 in $T_{1}, T_{2}$ and $T_{3}$, respectively. Alim (2013) stated that the benefit-cost ratio was $1.35,1.52$ and 1.30 in $T_{1}, T_{2}$ and $T_{3}$, respectively which is lower than our present findings. So it can be concluded that the benefit-cost ratio $(B C R)$ in $T_{1}$ was more beneficial than $T_{2}$ and $T_{3}$.

\section{Summary and Conclusion}

An investigation on "Impact of stocking density on the growth and production of Vietnamese koi at stocking density over a period of 90 days from $1^{\text {th }}$ September 2014 to $30^{\text {th }}$ November 2014 in farm pond of Noha Aqua Farm at Muktagacha region of Mymensingh. Three treatments such as $T_{1}, T_{2}$ and $T_{3}$ each having two replications which were chosen randomly and Vietnamese koi fry were stocked as 150 fish/dec $\left(T_{1}\right), 250$ fish/dec ( $\left.T_{2}\right)$ and 350 fish/dec $\left(T_{3}\right)$ respectively. Fishes were fed on commercial feed. The initial average weight of the fingerlings were $1.0 \mathrm{~g}$. Variation of water quality parameters were observed among the different treatments and all the values were within the acceptable and suitable range for Vietnamese koi culture. Under the experimental condition, different treatments showed different growth rates. From the present experiment, it was found that the total production was increased with the increase of stocking density. But the individual fish growth rate was decreased with the increase of stocking density. From this experiment, it was found that the highest net profit was BDT 32,690in $T_{1}$ followed by BDT 36,104 in $\mathrm{T}_{2}$ and BDT 38,450 in $\mathrm{T}_{3}$. That time the market price was BDT 130/kg fish. Culture of Vietnamese koi at stocking density (150 fish/dec) showed higher benefit in short period of time. The benefit cost ratio was 1.7, 1.63 and 1.56 in $T_{1}, T_{2}$ and $T_{3}$, respectively. Present findings indicated that comparatively highest individual weight gain was found in treatment $T_{1}$ which received lower stocking density (125 fish/dec). Water quality parameters were found within suitable range. From the experiment it might be suggested that the stocking density (150 fish/decimal) performed the better results and further study is needed to explore the economics of Vietnamese koi farming with different stocking densities.

\section{REFERENCES}

1. Ahmed GU, Aktar H, Chakma S, Hasan NA, M Shamsuddin, 2015. Comparative study on growth of super male tilapia and monosex tilapia in earthen mini pond. Research in agriculture, livestock and fisheries, 2: 169-175.

2. Ahmed GU, Sultana N, Shamsuddin M and Hossain MB, 2013. Growth and production performance of Monosex Tilapia (Oreochromis niloticus) feed with homemade feed in earthen mini ponds. Pakistan Journal of Biological Sciences, 16: 1781-1785.

3. Alim A, 2013. Effects of stocking density on growth and production performance of mono-sex Tilapia (Oreochromis niloticus) in ponds, MS Thesis, Department of Aquaculture, Bangladesh Agricultural University, Mymensingh.

4. Aminul IM, 1996. Qualities of water and soil in Aquaculture, Fish week compilation, 96. DoF Publication, Ramna, Dhaka-1000.

5. Begum M 2009. Effects of stocking density on growth and production performance of mono-sex Tilapia (O.niloticus) in ponds, MS Thesis, Department of Aquaculture, Bangladesh Agricultural University,Mymensingh. 
6. Dewan S, MA Wahab, MCM Beveridge, MH Rahman and BK Sarker, 1991. Food selection, electivity and dietary overlap among planktivorous Chinese and Indian Major carp fry and fingerlings grown in extensively managed, rain-fed ponds in Bangladesh. Aquaculture and Fisheries Management, 22: 277-294.

7. DoF (Department of Fisheries) 2002. Matsha Pakka Sankalan. Directorate of Fisheries, Bangladesh 11: 34-81.

8. DoF, 2011-2012. Fisheries Statistical Yearbook of Bangladesh (July 2011-June2012), Department of Fisheries, Ministry of Fisheries and Livestock, Bangladesh.

9. Haque ABMM 2014. Optimization of stocking density on growth and production performance of mono-sex tilapia in pond, MS Thesis, Department of Aquaculture, Bangladesh Agricultural University, Mymensingh.

10. Hasan SJ 2007. Effects of stocking density on growth and production of GIFT Tilapia (Oreochromis niloticus), MS Thesis, Department of Aquaculture, Bangladesh Agricultural University, Mymensingh.

11. Israfil E. H. 2000. L.R. Kabir 2003. Effects of chemical parameters on Eshakha lake in BAU campus. An M.S. thesis submitted to the Department of Fisheries Biology and Limnology, Bangladesh Agricultural University, Mymensingh, Bangladesh. 86 pp.

12. Israfil, M. 2000. Effects of periphyton on monoculture of Thai Sharputi (Puntius gonionotus). M. S. Thesis, Department of Fisheries Management, Bangladesh Agricultural University, Mymensingh.

13. Kabir ANMA, 2003. Use of duckweed (Lemna minor) as feed for fishes in polyculture. M. S. Thesis, Department of Fisheries Management, Bangladesh Agricultural University, Mymensingh. 74 pp.

14. Kohinoor AHM, Akhteruzzaman M and Shah MS, 1991. Observations on theinduced breeding of koi fish (Anabas testudineus, Bloch) in Bangladesh.Bangladesh Journal of Fisheries Research 14: 7377.

15. Kohinoor AHM, Islam AKMS, Jahan DA, Zaher M, Hossain MG 2007: Monoculture of climbing perch, Thai koi (Anabas testudineus,Bloch) under different stocking densities at on-farm management. Bangladesh Journal of Fisheries Research 11: 173-180.

16. Kohinoor AHM, Khan MM, Ahmed SU, and Hussain MG 2009: Culture potentials ofclimbing perch (Anabas testudineus, Bloch) under different stockingdensities at semi-intensive management. Bangladesh Journal of FisheriesResearch 2: 115-120.

17. Kohinoor AHM, 2000. Development of culture technology of three small indigenous fish mola (Amblypharyngodon mola), punti (Puntius sophore) and chela (Chela cachius) with notes on some aspects of their biology. Ph.D. Thesis, Department of Fisheries Management, BAU, Mymensingh. $363 \mathrm{pp}$.

18. Rahim A, 2010. Effects of stocking density on growth and productionperformance of mono-sex Tilapia (O. niloticus) in ponds, MS Thesis, Department of Aquaculture, Bangladesh Agricultural University, Mymensingh.

19. Rahman MS, 1992. Water Quality Management in Aquaculture. Published byBangladesh Rural Advancement Committee.pp.75.

20. Saha KC, 1971. Fisheries of West Bengal, Government Press, Alipore, WestBengal, India.pp.26.

21. Wahab MA and MK Ganapati, 1994. Seasonal changes in the physico- chemical parameters of garden pond containing abundant aquatic vegetation J. Magalaya Univ. 13: 55-67. 